Supplement of Clim. Past, 16, 51-64, 2020

https://doi.org/10.5194/cp-16-51-2020-supplement

(C) Author(s) 2020. This work is distributed under

the Creative Commons Attribution 4.0 License.

(c) (1)

Supplement of

\title{
Reconstruction of the track and a simulation of the storm surge associated with the calamitous typhoon affecting the Pearl River Estuary in September 1874
}

Hing Yim Mok et al.

Correspondence to: Dick Shum Lau (dslau@hko.gov.hk)

The copyright of individual parts of the supplement might differ from the CC BY 4.0 License. 
Section S1: Extract from The Selga Chronology (Part I: 1348-1900) with information on the 1874 typhoon (R. García-Herrera, P. Ribera, E. Hernández, L. Gimeno:'Typhoons in the Philippine Islands 1566-1900'. Submitted to Journal of Climate.)

The dawn of the 21st in Vigan was cloudy and rainy. The barometer registered $745.5 \mathrm{~mm}$ with calm. At four o'clock in the afternoon, it began to rain aplenty. The barometer registered $741.5 \mathrm{~mm}$ with a slight wind from the SW which continued until midnight, when it veered to the $W$ and reached hurricane force. The barometer remained at $745 \mathrm{~mm}$ until 8 in the morning when the wind backed to SSW and to the $S$ with much rain; the barometer at $747.7 \mathrm{~mm}$. At midday perfect calm; and the barometer began to rise; in the afternoon it cleared up with a slight wind from the S. Jose Serra described in this guise the effects of the storm which burst over Batan Islands on the 22nd of September, 1874: "At twilight on the 21st of September, the barometer began to descend in a conspicuous manner. At 8 at night, a strong NNE wind began to blow, while the barometer continued its rapid fall. At 10, a hurricane of extraordinary intensity was present. The aneroid barometers registered $737.0 \mathrm{~mm}$ ay 11 , the wind veered to the NNE with frightful violence, while the barometer continued its descent. From this hour until 1 , the wind blew with such a terrifying violence that the aneroides dropped 0.20 , until they registered $724.0 \mathrm{~mm}$. At the said hour, the wind veered to the $E$, where it acquired its maximum intensity, and produced the greatest havoc. From this hour, the barometer began to rise as fast as it had fallen. At 4, the SE wind began to blow, and at 5, I was able to go out and visit the town. The typhoon was over, but it left in its trails desolation and death. This island, being very small, and very near to Sabtang and Isbat the typhoon was experienced in all these places with the same intensity as in the capital. The churches and mission houses received damages, especially on the roofs. The church of the town of San Carlos was completely destroyed. The tribunals and schools were left in pitiable state. Seven houses made of lime and stone in the capital collapsed. One hundred sixty-four houses of wood and cogon were destroyed. It should not escape notice that while in Luzon houses were made earthquake proof, the natives in these isles make their cottages baguio proof, so that the devastating effects of the typhoons in these islands will ever be as great as in any town of Luzon. The winds of this storm were from the 1 st and 2nd quadrant. 
Table S1. Reports of pressure observations in Hong Kong and Macao during the passage of Typhoon 1874

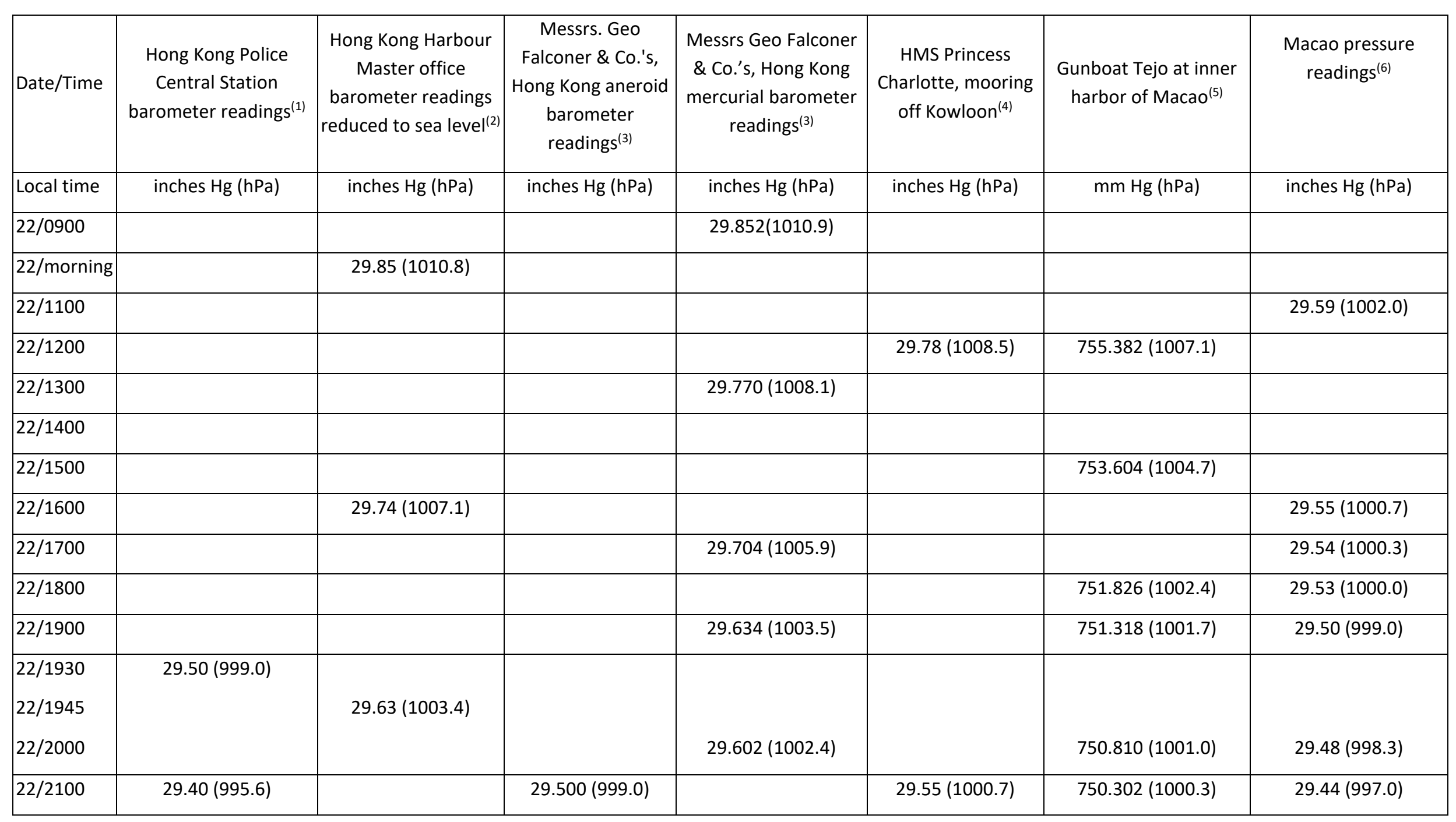




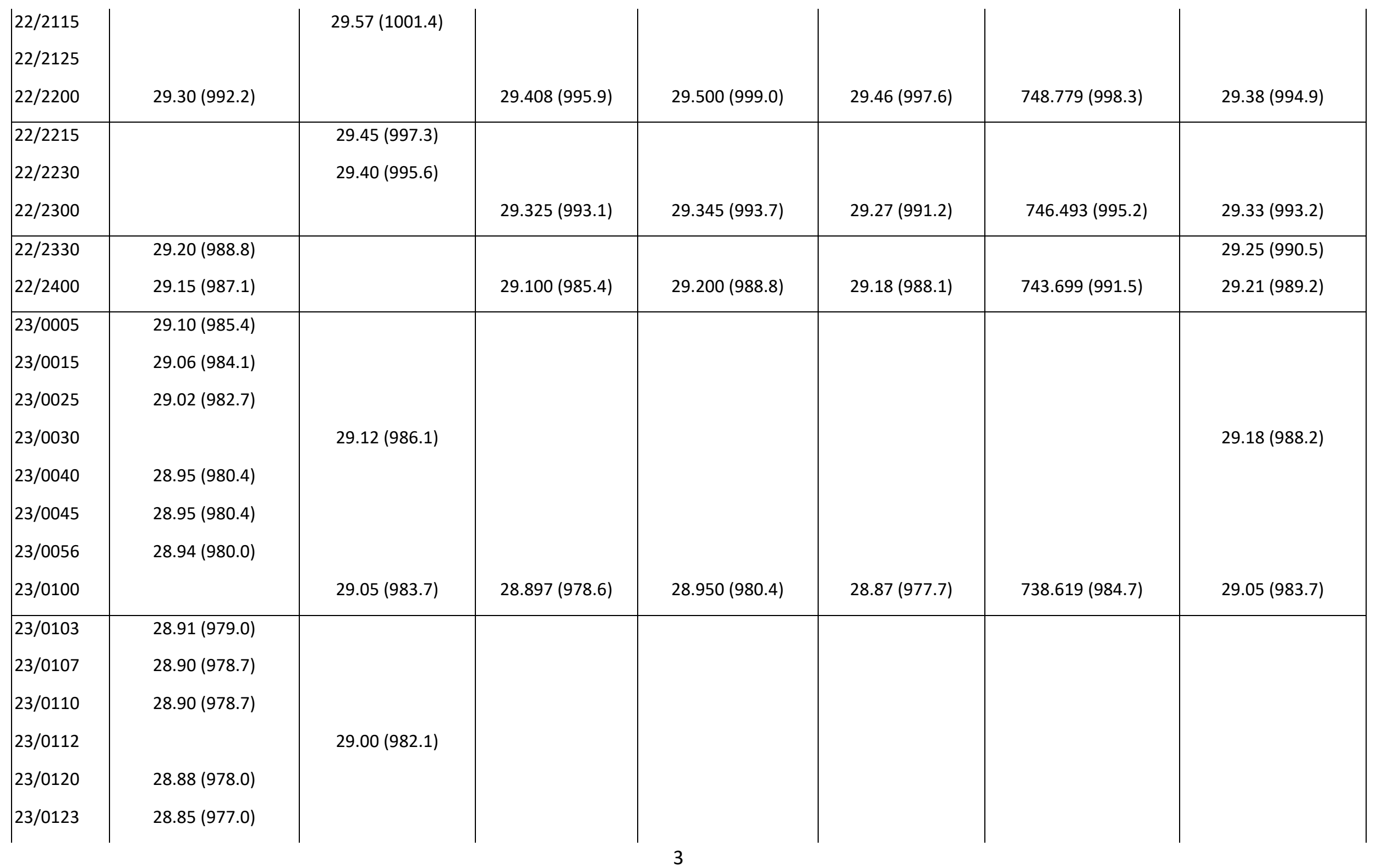




\begin{tabular}{|c|c|c|c|c|c|c|c|}
\hline $23 / 0127$ & $28.84(976.6)$ & & & & & & \\
\hline 23/0130 & & 28.95 (980.4) & & & & & 28.89 (978.3) \\
\hline 23/0134 & $28.82(976.0)$ & & & & & & \\
\hline 23/0137 & $28.80(975.3)$ & & & & & & \\
\hline $23 / 0143$ & $28.78(974.6)$ & & & & & & \\
\hline 23/0155 & $28.75(973.6)$ & & & & & & \\
\hline $23 / 0200$ & & $28.88(978.0)$ & 28.760 (973.9) & $28.870(977.7)$ & $28.83(976.3)$ & 731.761 (975.6) & $28.8(975.3)$ \\
\hline $23 / 0203$ & $28.73(972.9)$ & & & & & & \\
\hline 23/0215 & $28.77(974.3)$ & & $28.727(972.8)$ & $28.752(973.7)$ & & & \\
\hline $23 / 0220$ & $28.80(975.3)$ & & & & & & \\
\hline 23/0250 & $28.90(978.7)$ & & & & & & \\
\hline $23 / 0255$ & $28.95(980.4)$ & & & & & & \\
\hline 23/0300 & $28.97(981.0)$ & 29.04 (983.4) & 28.990 (981.7) & $29.235(990.0)$ & $29.12(986.1)$ & 715.759 (954.3) & 28.22 (955.6) \\
\hline $23 / 0305$ & $29.00(982.1)$ & & & & & & \\
\hline 23/0310 & $29.05(983.7)$ & & & & & & \\
\hline $23 / 0320$ & 29.10 (985.4) & & & & & & \\
\hline 23/0330 & $29.15(987.1)$ & & $29.184(988.3)$ & 29.286 (991.7) & & & 28.11 (951.9) \\
\hline
\end{tabular}




\begin{tabular}{|c|c|c|c|c|c|c|c|}
\hline $\begin{array}{l}23 / 0335 \\
23 / 0345 \\
23 / 0400\end{array}$ & $\begin{array}{l}29.20(988.8) \\
29.25(990.5) \\
29.28(991.5)\end{array}$ & 29.22 (989.5) & $29.320(992.9)$ & 29.315 (992.7) & $29.40(995.6)$ & 709.155 (945.5) & $27.94(946.2)$ \\
\hline $23 / 0410$ & & 29.32 (992.9) & & & & & \\
\hline $23 / 0415$ & & & & & & & $28.06(950.2)$ \\
\hline $23 / 0430$ & & & & & & & $28.23(956.0)$ \\
\hline $23 / 0445$ & & & & & & & 28.40 (961.7) \\
\hline $23 / 0500$ & & 29.49 (998.6) & & & $29.53(1000.0)$ & 724.809 (966.3) & 28.59 (968.2) \\
\hline $23 / 0515$ & & & & & & & $28.77(974.3)$ \\
\hline $23 / 0530$ & & & & & & & 28.98 (981.4) \\
\hline $23 / 0615$ & & & & & & & 29.25 (990.5) \\
\hline $23 / 0630$ & & & & & & & $29.28(991.5)$ \\
\hline $23 / 0700$ & & & & & $29.72(1006.4)$ & 749.540 (999.3) & $29.33(993.2)$ \\
\hline $23 / 0730$ & & & & & & & 29.42 (996.3) \\
\hline $23 / 0800$ & & & & & 29.79 (1008.8) & $753.604(1004.7)$ & $29.47(998.0)$ \\
\hline $23 / 0815$ & & 29.80 (1009.1) & & & & & \\
\hline $23 / 0830$ & & & & & & & 29.52 (999.7) \\
\hline
\end{tabular}




\begin{tabular}{|c|c|c|c|c|}
\hline $23 / 0900$ & & $29.82(1009.8)$ & $755.382(1007.1)$ & $29.55(1000.7)$ \\
\hline $\begin{array}{l}23 / 0930 \\
23 / 1000\end{array}$ & $29.84(1010.5)$ & $29.87(1011.5)$ & & $29.58(1001.7)$ \\
\hline
\end{tabular}

1 Published in the Hong Kong Government Gazette of 17 Oct 1874.

2 Published in the Hong Kong Government Gazette of 17 Oct 1874 (readings for 22/morning, 22/1600, 22/2230 and 23/0200) and The China Mail of 23 Sep 1874 (others).

3 Published in the China Mail of 23 Sep 1874.

4 Logbook of HMS Princess Charlotte.

5 Observations of Gunboat Tejo published in the Bulletin of the Macao Province and Timor Anno, 1874-Vol. XX- No. 41 Saturday 10 October.

6 Report of Port Captain of Macao published in the Bulletin of the Macao Province and Timor Anno, 1874-Vol. XX- No. 44 Saturday 31 October.

Note: the following conversion factors have been adopted:

(i) 1 inches of mercury $=33.86395 \mathrm{hPa}$

(ii) $1 \mathrm{~mm}$ mercury $=1.33322387 \mathrm{hPa}$

Reference: Smithsonian Meteorological Tables, $4^{\text {th }}$ revised edition, 1918 
Table S2. Reports of winds in Hong Kong and Macao during the passage of Typhoon of 1874

\begin{tabular}{|c|c|c|c|c|c|c|c|c|}
\hline \multirow{2}{*}{\begin{tabular}{|l} 
Date/Time \\
Local time
\end{tabular}} & \multicolumn{2}{|c|}{$\begin{array}{l}\text { Wind reports in Hong Kong } \\
\text { Police Central Station }\end{array}$} & \multicolumn{2}{|c|}{$\begin{array}{l}\text { Wind reports in Hong Kong } \\
\text { Harbour }\end{array}$} & \multicolumn{2}{|c|}{$\begin{array}{l}\text { Wind reports by HMS Princess } \\
\text { Charlotte }{ }^{(2)^{*}}\end{array}$} & \multicolumn{2}{|c|}{ Wind reports in $\mathrm{Macao}^{(3)}$} \\
\hline & Direction & Beaufort Force & Direction & Beaufort Force & Direction & Beaufort Force & Direction & Beaufort Force \\
\hline $22 /$ morning & & & NW & & & & & \\
\hline $22 / 1200$ & & & & & $\mathrm{~N}$ & 4 & $\mathrm{~N} / \mathrm{NNE}$ & 4 \\
\hline $22 / 1500$ & & & & & & & $\mathrm{~N}$ & 3 \\
\hline $22 / 1600$ & & & NNW & Fitful gusts & $\mathrm{N}$ & 6 to 7 & & \\
\hline $22 / 1800$ & & & & & & & NW & 5 \\
\hline $22 / 1900$ & & & & & & & NW & 5 \\
\hline $22 / 2000$ & & & & & $\mathrm{~N}$ & 4 to 6 & & \\
\hline $22 / 2100$ & & & & & & & NNW & 6 \\
\hline $22 / 2200$ & Gusts hea & and frequent. & & & & & NNW & 7 \\
\hline $22 / 2230$ & & & $\mathrm{~N}$ & & & & & \\
\hline $22 / 2300$ & & & & & & & NNW & 8 \\
\hline $22 / 2330$ & Shift & to 70 . & & & & & & \\
\hline $22 / 2400$ & & & & & NNE & 8 to 10 & NNW & 10 \\
\hline
\end{tabular}




\begin{tabular}{|c|c|c|c|c|c|c|c|}
\hline $23 / 0045$ & Gusts light & & & & & & \\
\hline $23 / 0100$ & & & & NE & 8 to 11 & NNW, N & 10 \\
\hline 23/0107 & Gusts heavier & & & & & & \\
\hline 23/0123 & $\begin{array}{r}\text { Gusts heav } \\
\text { inte }\end{array}$ & & & & & & \\
\hline 23/0200 & & $\begin{array}{l}\text { Suddenly shifted to } \\
\mathrm{NE} \text { and then to ENE }\end{array}$ & $\begin{array}{l}\text { Terrible } \\
\text { violence }\end{array}$ & ENE & 9 to 12 & $\mathrm{~N}$ & 11 \\
\hline $23 / 0300$ & & & & ESE & 10 to 12 & $\mathrm{~N}$ & 12 \\
\hline $23 / 0400$ & & & & ESE & 10 to 12 & NE, ENE, NW, E, SE & 12 \\
\hline 23/0405 & $\begin{array}{c}\text { Gradually } \\
\text { veered to SE }\end{array}$ & & & & & & \\
\hline $23 / 0500$ & & & & SE & 7 to 9 & SE & 12 \\
\hline $23 / 0600$ & & & & SE & 7 to 9 & SSE & 11 \\
\hline $23 / 0700$ & & & & SSE & 7 to 8 & SSE & 11 \\
\hline $23 / 0800$ & & & & SSE & 7 to 8 & S & 9 \\
\hline $23 / 0900$ & & & & SSE & 7 to 8 & $\mathrm{~S}$ & 6 \\
\hline $23 / 1200$ & & & & SSE & 3 to 6 & $S$ & 4 \\
\hline
\end{tabular}

* There were uncertainties in reading some of the hand-written characters.

1 Published in the Hong Kong Government Gazette of 17 Oct 1874.

2 Logbook of HMS Princess Charlotte.

3 Observations of Gunboat Tejo published in the Bulletin of the Macao Province and Timor Anno, 1874-Vol. XX- No. 41 Saturday 10 October 